\title{
The debate between the Austrian School of Economics and the cooperative movement. The assumption of unequal perception among agents
}

\author{
- Estrella TRincado \\ Universidad Complutense de Madrid
}

\section{Introduction}

Mises made some observations on cooperative businesses, i.e., firms collectively owned and run by their workers. These firms may perfectly emerge in a free society, however, for Mises the elimination of the private businessman was a sacrilege. Not everybody can be a businessman, as the cooperative ideas tend to imply. The businessman is one especially perceptive agent whose existence is central to the market economy. This agent needs encouragement and he needs to think on his own to have clear ideas: Mises describes him as the talented individual. The businessman seems to have different psychological features than the common people. His existence does not increase, but reduces, sales costs. Mises claims: "In terms of popular psychological teaching we can say that some have the ability to adjust themselves better than others to the conditions of the struggle for survival. We may therefore - without indulging in any judgment of value - distinguish from this point of view between superior men and inferior men" (Mises 1961, 190). Mises assumed the existence of "better races" and for him, the masses do not think (Mises, 1961, pp. 195-6). "They did not fail to see that the immense majority of common men are both too dull and too indolent to follow and to absorb long chains of reasoning" (Mises, 1969, p. 16). Thinkers in a market economy are, of course, entrepreneurs. In short, Mises presents an elitist vision of the market in which there is a natural inequality that needs to be recognized and that precludes cooperative business from the market economy. In order to encourage entrepreneurship and risk-taking individuals, this inequality is, and must be, the basis for wealth inequality. 
Permit me to recapitulate some well-known facts. While under precapitalistic conditions superior men were the masters on whom the masses of the inferior had to attend, under capitalism the more gifted and more able have no means to profit from their superiority other than to serve to the best of their abilities the wishes of the majority of the less gifted" (ibid).

Mises thought that Eurocentrism was the proper outlook (see Tucker and Rockwell, 1991).

But is this elitism part of the core of Austrian methodology or is it only a part of Mises theory? This article will try to ascertain if the Austrian School of Economics defends an unequal psychology of the agents. For this purpose, it deals with the debate on the cooperative movement as, conversely, the cooperatives assume equality of entrepreneurial abilities.

\section{Carl Menger's concept of the entrepreneur}

For F. A. Hayek (1992, p. 62), the Austrian school's "fundamental ideas belong fully and wholly to Carl Menger. ... [W] hat is common to the members of the Austrian school, what constitutes their peculiarity and provided the foundations for their later contributions, is their acceptance of the teaching of Carl Menger". However, the precise contribution of Menger (1840$1921)$ is not clear. In particular, Menger's concept of entrepreneurship was not fully new. His ideas were based on Jean Baptiste Say's definition of the entrepreneur (actually, Say was the first to coin the term "entrepreneur" in 1803). For Say (1836, p. 78), the entrepreneur shifts economic resources out of an area of lower and into an area of higher productivity and greater yield (see Forget, 1999). But, the same as after Marshall (1890, book IV), who considered organization a fourth factor, Say values the entrepreneur not for being a risk-taker but predominately for being a "planner" (Brewer, 1992, p. 51). In this sense, Say was not at odds with Adam Smith's concept of the entrepreneur, although Say did provide a praiseworthy description of the entrepreneur while Adam Smith distrusted his behaviour.

Indeed, according to Smith, what makes the capital increase is neither the major inventiveness nor the "exceptional man", but "the skill and judgment with which normally the work is done" (Smith, 1976, p. 27). ${ }^{1}$ Smith considered that the prudent man achieves the greater achievements in the market economy. He saves and invests to obtain the ordinary profit in lines of pro-

1. As Khan (1954) says, Smith gives importance to the role of capital and it is not industry but parsimony or abstinence the reason for gain. But once capital is being accumulated, money makes money almost in an immediate way. Based on this idea, Smith created a theory of stadiums in which development begins in small-scale agriculture. 
duction more or less known. He has the quality of abstinence and he is a man of slow but sure progress, who contents himself with small gains. He makes his projects with enough current information and taking into account the relation between expected profit and acceptable risk, provided that he knows that only if he saves he will be able to increase the quantity of his capital in a constant way. Then, Smith puts more emphasis on automatism to restore market equilibrium than on the innovative function of entrepreneurs (Trincado, 2009). But the problem with entrepreneurs is that sometimes they are haughty and imprudent people, and they do not take into account the unpredictability of time, subduing the investor to a moral risk under the bias of asymmetric information.

On the other hand, Say (1836) distinguishes the adventurer from the capitalist. The occupation of the adventurer is setting industry in motion, that is to say, the application of acquired knowledge to the creation of a product for human consumption. The adventurer requires a combination of moral qualities, judgment, perseverance, and knowledge of the world, as well as of business. He is called upon to estimate, with tolerable accuracy, the importance of the specific product, the probable amount of the demand, and the means of its production; in a word, he must possess the art of superintendence and administration. He must have a ready knack of calculation, to compare the charges of production with the probable value of the product when completed and brought to market.

The same as Say, what Menger wanted was to establish a causal link between the subjective values underlying the choices of consumers and market prices used in the economic calculations of businessmen. The process of imputing value from lower-order goods (consumption goods) to higher-order goods (production goods) is inseparable from the idea of time, a process of change inherently uncertain. This uncertainty associated with production can be greatly mitigated by the improvement of technological knowledge, which may be general or possessed in a monopolistic way by an agent who foresees desires, which are "planned and conducted... by an economizing individual" (Menger, 1976 [1871], pp. 159-60). In this sense, Menger seems not to be elitist in his understanding of the entrepreneur. He described the economizing individual as a coordinating agent who is both a capitalist and a manager. The entrepreneur owns resources and decides how they will be used. The entrepreneur's most important function is anticipating future desires, estimating their relative importance, and acquiring the technological knowledge of currently available means. But entrepreneurial activity comprises a number of additional functions: "economic calculation", involving the various computations needed to ensure the technical efficiency of the production process; "the act of will" by which higher-order goods are purposely allocated to the chosen production process; and "supervision" of the execution of the produc- 
tion plan so that it may be carried through as economically as possible. The last two functions entail property-ownership and, therefore, mark the Mengerian entrepreneur as a capitalist-entrepreneur (Salerno, 2000).

But then, what is Menger's contribution to the concept of the entrepreneur? His entrepreneur is no more than what Brunner and Meckling (1977) call the REMM: the resourceful, evaluating, maximizing man. As Schumpeter $(1969$, p. 86) alleges, his contribution to economics is not about the agent of the entrepreneur, but "the discovery that ... human needs are the driving force of the economic mechanism beyond the Robinson Crusoe economy or the economy without exchange. ... His essential aim is to discover the law of price formation".

\section{The roots of the Austrian Economics School's concept of the entrepreneur}

Menger published his principles in 1871 and by the mid-seventies his writing and teaching had begun to attract a number of brilliant followers, most notably Eugen von Böhm-Bawerk and Friedrich von Wieser, leading to an identifiable Austrian school. But, when dealing with the question of the entrepreneur, this Austrian School of Economics sided with another French tradition different from Say's theory. Not in vain, France was the birthplace of "mercantilism", which considered merchants the agents who have, and should have, a crucial role in economics, precisely what Adam Smith criticized. This other tradition traced its roots back through A. R. J. Turgot and Richard Cantillon to the scholastic writers of the Middle Ages and it was based not only on subjectivism, but also on phenomenalism and idealism as against Smithian realism (Trincado, 2006).

Those authors had Cantillon (1755) as a forerunner (see Brewer 1992). Cantillon introduced a specific concept of the entrepreneur (Nevin, 2013). Entrepreneurs, according to Cantillon, are agents who buy at a certain price and sell at an uncertain one and, so, they accept the risk of the market, making the circulation and the exchange of goods possible. "They pay a fixed price for them at the place where they are purchased, to resell wholesale or retail at an uncertain price. ... These entrepreneurs never know how great the demand will be in their city" (Cantillon, 1755, p. 74). But, more importantly, entrepreneurs are special agents distinguished by a lesser aversion to risk than the masses. They link different successive moments of time thanks to a special skill: the want of imagining the future. Actually, Cantillon divided society into two principal classes - fixed income wage-earners and non-fixed income earners (although there are other two classes: politicians and property owners, see Hülsmann, 2002, p. 698). Entrepreneurs, according to Cantillon, pay known costs of pro- 
duction but earn uncertain incomes, due to the speculative nature of pandering to an unknown demand for their product (see Tarascio, 1985). Furthermore, unlike later theories of entrepreneurship which saw the entrepreneur as a disruptive force, Cantillon anticipated the belief that the entrepreneur brought equilibrium to a market by correctly predicting consumer preferences.

This is also the stance of utilitarian authors of the nineteenth century based on philosophical individualism, the individual being the only judge of his own actions. These authors are actually the forerunners of marginalism and of Mises theory of the entrepreneur. Jeremy Bentham, who wrote quite original economic works on entrepreneurship in the late eighteenth century, such as Defence of Usury (1787) and Manual of Political Economy (1793), may be considered a forerunner of Austrian Economics (Trincado, 2004). For Bentham, the role of technological change in entrepreneurship and economic growth is very important, something he pleaded in defence of a free market, as the entrepreneur - the projector - in a centrally planned economy is not interested in the nurture of technological innovation for his own interest:

I mean projectors: under which invidious name I understand you to comprehend, in particular all such persons as, in the pursuit of wealth, strike out into any new channel, and more especially into any channel of invention...; whether it consist of the production of any new article adapted to man's use, or in meliorating the quality, or diminishing the expense, of any of those which are already known to us... whatever is now establishment, was not, at one time, innovation? (Bentham, 1818, p. 12).

With this concept of the entrepreneur, Bentham was criticizing Adam Smith and the fact that, although Smith knew Cantillon's work, he decided to present a person that decides and faces the risk as a routine (Spengler, 1975). Bentham reproaches Smith having underestimated the role of the "men of talent" that, thanks to their invention and imagination, are responsible for the progress and wealth of the nations, provided that they find new channels of trade and open new ways towards the future. Bentham speaks about the productivity increased by new arrangements of the means of production, especially in manufacturing. Innovation is the force that drives development because "what is now an institution, once was an innovation" (Stark, 1952, p. 355). Bentham also complains that Smith relates prodigals with speculators. The second follow routine models of behaviour, they stand out from the mass, so they are part of a very restricted elite that need courage and genius. Bentham shows here then an aristocratic conception and contempt of the common people. Projectors depart from routine patterns of behaviour, break away from the common herd; and in the process discover new markets, find new sources of supply, improve existing products, or lower costs of production. He mentions two cases in which cour- 
age, not genius, is necessary: the opening of a new market, and the search of a new source of supply. When we add two other determinants of innovation - the production of a new good, and the introduction of a new method of production - we have four of the five new combinations that Schumpeter (1934 [2008]) details in "Theory of economic development". The businessman introduces improvements, and here, Bentham uses italics for the word improvement due to the fact that he distinguishes between improvement (a new method of combining resources for productive purposes) and invention (scientific progress). Projectors create utility, Bentham (1952, p. 170) argued, by effecting improvements, whether such improvements consist in the production of any new article adapted to man's use, or in meliorating the quality, or diminishing the expense, of any of those which are already known to us (see Stark, 1952a, 170) from Defence of Usury and Hébert and Link $(2006,302)$.

As Pesciarelli (1989) says, Smith considered the "ideal man" the current and frugal man whereas Bentham - and Schumpeter - enthrones the exceptional and adventurous individual. Schumpeter $(2008$, p. 70$)$ even said that talent "rides to success on its debts". According to the Smithian theory, this idea of managerial activity introduces a Messianism, similar to the one introduced by mercantilism with the state. Provided that the market or the individuals cannot face the process of growth, a Messiah with semi-divine characteristics is required. If Bentham shows an aristocratic attitude, Smith shows a certain preference for the middle and low conditions of society, and especially for the middle, the saving class according to Smith (1997, p. 132 and pp. 140-1). People from the middle classes who have not been born rich but who have a small quantity of capital save and invest it. As Santos (1997) says, we can relate this explanation to Milton Friedman's theory of consumption, based on the concept of "permanent revenue".

Curiously enough, against the definition of pleasure presented by Hume, for Bentham risk is a foreseen "pleasure" and the pleasures are more intense the more uncertain they are (Dube, 1991, p. 97). The function of the entrepreneur, then, is to capture the utility of the final good beforehand, foreseeing the pleasures of the public in a context of uncertainty. So, as we shall see, Bentham is close to the figure of the businessman described by Kirzner, in which the role of surprise and discovery are typical of the managerial creative function (see Kirzner, 1998: 275-6 in Annex; and Huerta de Soto, 2000: 189).

\section{Austrian economics versus the cooperative movement in Vienna circles}

This concept of the entrepreneur by Bentham lies outside classical economics and is the basis for Mises theory. Mises relied on Cantillon's and Bentham's elitism in questions of entrepreneurship. For a better understanding 
of this idea, we are going to turn to the debates on cooperatives and socialist calculation.

The champions of cooperative organizations assume equality in managerial abilities and are against the particularity of the agent or the entrepreneur. Everybody has a calculating ability; in social terms, this also means that the state may calculate, as particular agents calculate in the market. So, they defend an anti-elitism that pleads for a change in society that will lead to a self-management where people have the full stake in matters that affect their lives.

Within the Vienna circles, Friedrich von Wieser wrote a piece on the cooperatives (Genossenschaften) favouring social economics and a mixed economy in the tradition of the eighteenth century Cameralism, in contrast with Menger's individualism (Chaloupek, in Cardoso and Psalidopoulos, 2016, 10). Besides, John O’Neill (1988) points to epistemological parallels between Hayek and Otto Neurath, who advocated a kind of "associationist socialism" in which meso-level social institutions (like cooperatives) would play a major role. But looking at the official academic representatives of the economic theory of cooperatives at Vienna University (Genossenschaftswesen), we see that they often belonged to the collectivist camp (Spann circle), not to the individualist school of Carl Menger.

The reason was the influence of Othmar Spann. Spann was an Austrian philosopher who was a key influence on German conservative and traditionalist thought in the period after World War I, the New Right (Sunic, 1990). He defended universalism based on nationalistic values and collectivity, totality or whole (Spann, 1930, 61). This was a denial of individualism and the atomistic view of the market. Like Adam Müller, who was under the sway of the Romantic School (Müller, 1812), Spann rejected both capitalism and socialism, and advocated a corporatist system relatable to the guild system of the Middle Ages. There, fields of production were organized into corporations directed by administrators in service to the state. According to him, extreme competition creates disharmony and weakens the spiritual bonds between individuals (Spann, 1930, 162). Although Spann was not Marxist, he said that "Marx nevertheless did good service by drawing attention to the inequality of the treatment meted out to worker and to entrepreneur respectively in the individualist order of society" (ibid, 226). Spann held that all individuals in society should hold the same position, eliminating all class distinctions, and should receive the same amount of goods. However, democracy in political systems was completely rejected by Spann with the argument that the manipulation of government by wealthy capitalists and financiers with questionable moral character and goals was in disagreement with the good of the community. Besides, he considered that people are unequal in qualities and thus are suited for different positions in the social order. Democracy, by allowing a mass of people to decide governmental matters, meant 
excluding the right of superior individuals to determine the destiny of the state. Spann noted that "demands for democracy and liberty are, once more, wholly individualistic" (Spann, 1921, p. 111, quoted in Wassermann 2010, p. 80). So, he defended the "subordination of the intellectually inferior under their intellectual betters" (Spann, 1921, p. 185, quoted in Wassermann 2010, p. 82). Individuals who demonstrate their leadership skills and right ethical character would rise among the levels of the hierarchy.

The early success of the Austrian School came to an end with the collapse of the Austro-Hungarian Empire in 1918, as in the new republican atmosphere many Marxists began to take positions of power. To his students, Mises lacked the fame and brilliance of other professors of the department of law and government science, such as Spann (see Hülsmann, 1989, 2f). Mises - and Wieser - dealt with technicalities of the marginal value analysis, Spann confronted the students with a broad picture of social life, and he also impressed young scholars of the Austrian School such as Hayek and Morgenstern. However, in the University of Vienna, the students who did not share Spann's aesthetic, epistemological and political orientations - a minority - found an alternative in the courses of Friedrich von Wieser who, in the years after World War I and up to his death in 1926, was the unquestioned authority in general economic theory in Vienna. Even in the field of the theory of money, banking and business cycles, and of socialism, Mises was not the very highest authority, as Wieser pioneered the Austrian theory of money (see Hülsmann, 2007, 471).

However, Hayek and others, such as Haberler, Strigl and Machlup, worked with Mises for more than ten years. Not in vain, Mises' criticism of Spann's idea of the community avoided him being linked to the leaders of the so-called "Austro-fascist state", including Von Starhembert, Engelbert Dollfuss and Kurt Schuschnigg, so influenced by Spann's ideology (Bischof et al, 2003). But Mises did not raise a "school" of disciples advocating his doctrines and, to no small extent, this was due to his ideal of individualism (Hülsmann, 2007). Mises had stepped into the idealism of Schiller, Heder and Humbold, and considered the free development of the individual to be the supreme goal of human achievement. However, Mises later made it clear that his rejection of Spann's approach had nothing to do with a dogmatic insistence on the virtues of methodological individualism; the point was, rather, that the nature of science according to him was to deal with parts, rather than with wholes, studying the interrelations of those parts (see the discussion in Mises [1933] 2003, $42-50){ }^{2}$

2. Also personal differences were underlying, as Spann was influenced by anti-Semitism and Mises was a Jew. 
Thanks to Hanks Mayer's presence, the Wieserian paradigm was dominant in Vienna long after Wieser's death. Actually, Mayer obtained Wieser's chair; although there were more prominent economists as candidates, such as Joseph Schumpeter, who at that moment held a position at the University of Bonn, and Gustav Cassel from Sweden, who promoted Walrasian mathematical economics and was famous for his rejection of utility theory as a foundation of price theory. So, the fourth generation of the Austrian School was introduced to Austrian economics primarily through the works of Wieser. Wieser - and F. A. Hayek - emphasized knowledge, discovery and market process. Wieser saw the entrepreneur as owner, manager, innovator, organizer and speculator and, without the market, he would not have the information given by prices; but he has no special gift to solve the problem of uncertainty.

So what happens with Mises then? Besides interest, the central novelty of Mises analysis of the market economy seems to be his emphasis on the role of the entrepreneur. But he was taking Cantillon's and Bentham's idea of the entrepreneur and, although he got rid of Spann's idea of subordination, he maintained Spann's ideas of inequality, in this case applied to the agent of the entrepreneur (Mises, 1990).

Mises made a distinction between entrepreneurs who take successful action in an uncertain world, and entrepreneurship in the sense of a fundamental economic function - the bearing of risk under uncertainty (see Hülsmann, 2007, 764). Mises made some observations on the cooperative movement. Cooperative businesses, that is to say, firms collectively owned and run by their workers, may perfectly emerge in a free society. However, Mises takes pains criticizing their existence and showing their inefficiency. The cooperative movement set out to abolish the wages system and give a share to each worker in the property and products of the firm where he is employed. For Mises, cooperatives are not a method of world reconstruction. The cooperative movement struggled for the elimination of entrepreneurs and capitalists altogether as "useless exploiters". But, for Mises, the elimination of the private businessman, the "middleman", is a sacrilege. This perceptive agent needs to think on his own. He needs solitude and encouragement to have clear ideas, as he is describes as the talented individual. His existence does not increase, but reduces sales costs. According to Mises, cooperatives cannot stand the competition of private business without the aid of special governmental privileges and favouritism. Besides, he says, cooperatives of the time were not based on an ideal of direct cooperation. They were big businesses with millions of members who never met one another. They were organized in a complicated hierarchy. The competitive market economy is, Mises says, more democratic than the cooperative organization as it is essentially social cooperation under the division of labour for the production of goods and services consumers want to use. So, private profit-seeking 
businesses, not cooperatives, are harbingers of economic improvement (Mises, 1990).

Mises points out that there is no freedom in "laws of nature". The concept of freedom, and its antithesis, makes sense only in referring to conditions of social cooperation, which is the basis of any really human and civilized existence. Only in a free society, Mises says, one has the individual the power to choose between morally praiseworthy and morally reprehensible conduct. $\mathrm{He}$ adds that:

The market economy is the full and only possible realization of the principle of economic democracy. The market process is a daily repeated voting in which every penny gives a right to vote. The buyers, by preferring those commodities which in regard to price and quality are best fitted to satisfy their needs, make and conduct of each enterprise profitable or unprofitable, make small-size business big and penniless beginners rich... It is true, these ballot papers are not equally distributed among the public.... But to be rich is in itself the outcome of a vote taken, as in the market economy not only the acquisition but no less the preservation of wealth requires continuous success in best supplying the consumers (Mises, 1990, 263).

Political democracy embodied in representative government is supposed to be the corollary of the economic democracy of the market. This system will preserve peace in both domestic and foreign affairs as, following Hume's claim, a government not supported by the majority must sooner or later lose its power as it can be violently brought down. This theory also implied a criticism of Austrian circles of power, maybe even at university:

A capitalist social order unhampered by interventions, therefore, provides for a permanent selection among the capitalists and entrepreneurs... Why can incompetent people in the German Reich and in Austria remain CEOs for many years? Because in an interventionist state these executives are selected primarily in regard to whether they enjoy a good reputation with the higher authorities... (Mises to Bermann, letter dated 10 September, 1931, Mises Archive, 95:22).

Schumpeter had a similar point to Mises when dealing with entrepreneurship. According to Schumpeter (2008), entrepreneurs are innovators who constantly interrupt the operation of a static economy. Innovation plays a central role in the market economy as entrepreneurs reap profits for innovation and, in this sense, he contradicts the Mengerian insight that all incomes depend on consumer wishes. Actually, Mises reconciled Schumpeter with Menger saying that entrepreneurs cannot earn a profit for innovation per se - only for innovations that improve the satisfaction of consumer 
wants. They constantly adjust the structure of production to what they expect will be the future preferences of consumers, with an expectation of profit in the future.

However, for Schumpeter (1942), as opposed to Mises, socialism can work and it will fit together with democracy. Capitalism cannot survive as it tends toward corporatism. The "creative destruction" that describes innovative entry by entrepreneurs is the force that sustains long-term economic growth, and this innovative quality makes capitalism the best economic system (see Heertje and Jan, 2006). But the intellectual and social climate needed to allow entrepreneurship to thrive will not exist in advanced capitalism; it will be replaced by socialism in some form. Majorities will vote for the creation of a welfare state and place restrictions upon entrepreneurship that will burden and eventually destroy the capitalist structure. In Schumpeter's view, socialism will ensure that the production of goods and services is directed towards meeting the "authentic needs" of the people - disregarding the purpose of the prices of disclosing the needs of the people - and will overcome some innate tendencies of capitalism, such as conjecture fluctuation, unemployment, and waning acceptance of the system.

\section{Other Austrian economists on entrepreneurship}

The Austrian line created by Mises seems to be based on philosophical individualism. Actually, one feature of the radical "subjectivism" of Austrian theory versus the classical school is the supremacy of strategic, self-interested behaviour that gives play to the Austrian theory of the entrepreneur, as against the neoclassical world, where explanations of economic phenomena consist of applications of cost-benefit calculus and maximization subject to constraint, a deterministic framework (Garrison, 1995). In the Austrian world, the market process is driven by alertness, or entrepreneurial discovery (Kirzner, 1989), that lies outside the cost-benefit calculus. Positing alertness, entrepreneurship is a sine qua non (Kirzner, 1979, p. 142). The subjective perception of information is an essential element in Austrian methodology (see Thornsen, 1992, and Kirzner, 1997, pp. 60-85).

Kirzner deals with the discovery of opportunity (Foss and Klein, 2012). The definition of the entrepreneur is the agent that deals with how, by whom and with what effects opportunities to create future goods and services are discovered, evaluated and exploited. Kirzner argues that a competitive market is superior because it best generates entrepreneurial discoveries. Rothbard (1974) criticized Kirzner for not emphasizing the role of entrepreneur as uncertainty-bearer, the same way as Mises had emphasized that the entrepreneur has an anticipative understanding of an uncertain future. However, Kirzner 
makes abstractions to establish that the "pure" entrepreneur is an individual who only performs a discovery function. He discovers new resource uses, new products, new markets, and new possibilities for arbitrage. Entrepreneurship is the act of grasping and responding to profit opportunities. The pure entrepreneur is one who owns nothing at all. Market equilibrium is, in essence, an imaginary construct in which individuals have perfect knowledge, resources are dispersed perfectly according to everyone's preferences. Therefore profits and losses do not exist in market equilibrium. Kirzner argues that the entrepreneur's main effect is to push the economy closer to market equilibration. In short, he is an equilibrator.

However, according to Kirzner, alertness is exercised costlessly, and so any after-tax profits at all should suffice to call it forth. But then, why should costless alertness not be always exercised to the fullest, independently of the existence of a free or a regulated market? Shmanske provided an insightful answer to these riddles by distinguishing between developing the capacity to be alert to profit opportunities and actually exercising the alertness. Cost-benefit analysis applies to the developing but not to the exercising. Shmanske deals with the costs of discovery. According to Shmanske (1994, p. 208), the individual starts to think about formulating a new plan in an instant, so there is an optimal rate of adjustment to the post-discovery situation, and the capacity for alertness will be greater in a market-oriented, low-tax economy. He argued that those bold spirits - entrepreneurs - created technical and financial innovations in the face of competition and falling profits and generated irregular economic growth.

Kirzner's approach has been much debated within the Austrian School of Economics. His conception of the entrepreneur is by no means the dominant one among Austrians. In fact, it is not Mises' idea. For Mises, the entrepreneur is a resource allocator, not an equilibrator. Good entrepreneurs earn profits while less capable ones earn losses. They attempt to anticipate the future demands of consumers and satisfy them. So, the same as Frank Fetter (1977), he considers human action and uncertainty-bearing the unit of analysis, not the abstract "opportunities".

In this sense, Fetter is the one who better follows the idea of Mises in his Economic Principles (1915). Fetter (1977) saw the entrepreneurial function as the key. He asserted that an entrepreneur organized and directed production while possessing superior foresight. Fetter's theory has been briefly outlined in Salerno (2008). He anticipated Knight's distinction between risk and uncertainty. "The primary function of enterprise is the choice of a business in which to invest; the next, and essentially last function, is to provide competent management" (Fetter, 1915, p. 327). The entrepreneur must evaluate production decisions and guide the production process through the selection of superior managers $(1915,327-342)$. Fetter goes on to emphasize the impor- 
tance of the uncertainty of business conditions for these entrepreneurial judgments. This is the same distinction between entrepreneurs and managers drawn by Ludwig von Mises (1963). For Fetter, entrepreneurs differ from simple risk-bearers:

The risk of business is not that of the throwing of dice in which (if it is fair) skill plays no part and gains in the long run offset losses. Business risk is rather that of the rope-walker in crossing Niagra; the task is easily undertaken by the skilful Blondin, it is fatally dangerous to the man of unsteady nerve and limb (Fetter, 1915, p. 359).

In this case, personal skill and intuition are used to deal with non-measurable risks. Individual aptitude and insight are the key ingredients in dealing with this type of non-quantifiable risk. Fetter also describes entrepreneurs as relieving labourers and capitalists of the uncertainty involved in their employments, in other words, from unforeseen, potentially damaging, fluctuations in price (Fetter, 1915, pp. 364-365). This specialization in risk-taking is a form of insurance to those whose income is thereby rendered more certain. Personal prescience regarding the future movements of market forces - and acting based on it - is an essential part of entrepreneurial judgment. The entrepreneur also deploys "superior knowledge and superior insight" (Fetter, 1977, p. 244), and personal qualities of "vigilance, strength, and self-assertion" (Fetter, 1915, p. 349). Fetter describes the entrepreneur as "the man who can see most quickly and clearly". It is evident then that judgment is intimately tied up with the personality of the entrepreneur, depending as it does on skills which are uncommon.

\section{Austrian theory of cooperatives and of the firm}

Due to its description of entrepreneurship, Austrian Economics has no real theory of the firm. In this sense, its disregard of cooperatives is equalized to the oblivion of hierarchical large firms - "Islands of conscious power in this ocean of unconscious co-operation", as Robertson (1923, 85) defines Coase's firms. However, its contributions could ultimately lead to an entrepreneurial theory of the firm based on the market process, property rights and the importance of information and tacit knowledge (Foss, 1997; Foss and Klein, 2002). For the Austrian School of Economics, the only condition for entrepreneurial competition is not to have restrictions at the entry. Monopoly is a result of government restrictions. Even antitrust laws should be repealed as they suppose a deterministic relationship between the market struc- 
ture and economic performance and they act against innovative business organizations (Armentano, 1999, p. Xi).

But surprisingly, as we have previously said, Friedrich von Wieser supported cooperative associations as an organizational form of large firms that could ameliorate the social condition of workers. He dealt with issues such as private ownership of the means of production and economic inequality, impact of collective bargaining on wage formation, and public economy, and he discussed the contribution of public sector production to social value (Chaloupek, 2006). Other Austrian economists have also defended cooperative organizations. Schweickart (1993) observes that the success of the Mondragon cooperative complex in the Basque Country indicates that a libertarian socialist economy can flourish. Carson (2004) reconciles the Austrian and Marxist anti-statist theories. He defends that the end of liberal democracy as a dominant political paradigm, and its replacement with philosophical anarchism and a decentralized and pluralistic political order, would naturally produce a brand new economic paradigm. The result could be an economic order where the worker-oriented firm replaces the capitalist corporation as the dominant mode of economic organization (Preston, 2003). Alan Carter (1992) defended workers' cooperatives rebutting the claim that they merely replace exploitation by employers with "self-exploitation". Carter says that this is non-sense because self-exploitation is a self-contradictory term. However, workers' co-operatives are still subject to "market exploitation" by dominant economic actors who are external to the co-operative (for this concept, see Bies, Tripp and Neale, 1993). According to John O'Neill, however, these conclusions are mistaken because "market exploitation" is difficult to operationalise and "self-exploitation" may have a respectable use when it is understood as "institutional exploitation". Carter responds that if people freely choose to organize themselves in a cooperative basis, the structure can provide the preconditions for a workable anarchy (Carter, 1992, 267).

On the other side, David Gordon (1996) says that in "team production", in which workers must coordinate their activities on a joint endeavour, a tendency is present for each individual to shirk. Why not, to the extent that one can get away with it, turn to other things and let one's fellow workers bear the brunt of the task? To deter this, monitoring is necessary. And the question at once arises: what form of monitoring is most efficient? Alchian gave strong reason to think that monitoring works better if the monitor's interests are independent from those of the workers. From the workers own viewpoint, it makes sense for them to hire themselves out rather than to manage their own work. They are likely to be more productive, and hence earn more money, if they do so. The open corporation, though it separates ownership from control of production, preserves many of the efficiency advantages of 
the classical firm. In addition, it enables vast sums of money for investment to be raised. ${ }^{3}$

\section{Debates on method and socialist calculation}

In general terms, Austrian Economics does not derive optimism concerning mankind's future evolution from their epistemological convictions. Mark Pennington has looked at the implications of "spontaneous order theories" for deliberative democracy and the "politics of difference" (see Pennington, 2000). The same as Mises, Rothbard (2000) argues against egalitarianism. Intellectuals must disseminate a correct grasp of how a market economy operates to teach those blinded by ignorance and emotions. He also believed in the superiority of the elite, and that society is filled with "ineducable masses" (Rothbard, 1978: 122). Just as an example: he does not attribute the problems of blacks or other minorities to racism and prejudice, but to parasitic values of idleness and irresponsibility found in those communities (Rothbard, 1978: 154).

However, Menger's fame was based on his criticism of elitism and the paternalism of aristocracy. Unlike Schmoller and his disciples, who defended government in the hands of the professors, the bureaucracy or the Junker aristocracy, Menger was highly critical of the higher Austrian aristocracy (see Moser, 1997). The Austrian economists reject the logical relativism implied in the teachings of the Prussian Historical School: there is a body of economic theorems valid for all human action irrespective of time and place. Intellectuals must disseminate a correct grasp of how a market economy operates to teach those blinded by ignorance and emotions. It is true that F. A. Hayek (1960) explained, "why I am not a conservative". For him, conservatism, until the rise of socialism, was opposite to liberalism. As conservatism does not indicate another direction than current tendencies, it cannot prevent their continuation. But the Austrian professor David Prychitko describes the political culture of his movement best: "Policy-wise, Austrians as a group tend to be political conservatives, although there are one or two of us (including yours truly) who question its strictly conservative ideology. And, like all other schools of thought, Austrians have their share of cranks, crackpots, and weirdoes, who are best left ignored" (Prychitko, 2005).

After 1819, the "Socialist Calculation" debate established the distinctive features of Austrian theory, particularly the theory of knowledge laid out in the seminal contributions by Friedrich von Hayek. Hayek (1945) claimed that prices are not merely rates of exchange between goods, but rather a mecha-

3. Marxists claim that workers serve capitalists because they are forced to do so, and thus there is not prevailing freedom. But, in general, Austrians views are based on negative freedom. 
nism for communicating information. In his 1944 The Road To Serfdom, he pointed out that tyranny is the political corollary of socialism. Hayek enlarged his ideas in The Constitution of Liberty (1960). Endorsing the famous Humean definition of liberty as the rule of laws and not of men, Hayek shows the legal requirements for maintaining a commonwealth of free citizens, a government by the people (representative government) instead of by an authoritative leader. He distinguishes between socialism and the welfare state: the welfare state is compatible with liberty under certain conditions. In Hayek (1988), the "fatal conceit" of Lange and other socialists was that they believed order could be "designed" by a planner who gets prices right. Socialists did not realize that limited knowledge constrains not only individuals but also planners. So, actually, entrepreneurs are not special agents that plan the future better than the mass. Simply, "spontaneous order" arises from the interaction of a decentralized group of self-seeking agents acting in a price system. Information is thoroughly distributed and the law of the big numbers makes the masses more informed than the elite, due to the statistical average.

Conversely, for Mises, the authoritarian mode of organization does not allocate resources according to their most highly valued use by individuals, but the market does (Streissler, 1988, p. 195). Even the welfare state transforms the market economy step by step into socialism. If the government does not repeal its first intervention, it is induced to supplement it by further acts of intervention, until all economic freedom has been virtually abolished. After leaving to the United States, Mises revised and expanded National okonomie into Human Action, which appeared in 1949. And this work remains the economic treatise that defines the Austrian School. Murray Rothbard established a theoretical framework for examining the effects of intervention in the market. He expressed sympathy for many of the criticisms of state capitalism advanced by the classical socialists, including Marx and Bakunin. However, he attacked them for blaming the market rather than the state for the exploitation inherent in state capitalism. For Rothbard, the principal error of most of traditional socialism was its effort to achieve socialism by the reactionary methods of statism and militarism (see Raimondo, 2000). However, Rothbard (1962), in Man, Economy, and State, roots the Austrian School's approach on a natural-rights theory of property and the defence of a capitalist and stateless social order. In 1991, Professor Ebeling consulted with members of the Russian Parliament in Moscow on free market reform and privatization of the socialist economies (Ebeling, 1994) in the former Soviet Union and Eastern Europe (Ebeling, 1996), as well as on economic policy in the United States (Ebeling, 1995). The Austrian economist Boettke (2004) argues that Austrian libertarianism can be viewed as an impetus for a progressive research programme in political economy that addresses issues of social cooperation in case of conflict. 
Many Austrians argue against political unification and cooperation, as is the case with Röpke. Wilhelm Röpke (1959) and the Ordoliberals think it possible to be internationalist on trade and isolationist in politics. The smaller the political unit, the closer government will be to the people, which means it will be easier to keep it in check and macroeconomic planning will be less feasible. At the same time, smaller political units are more dependent on trade with their neighbours, helping to build peace. Röpke opposes all post-war efforts to create a world government. He opposed the World Bank and the IMF, predicting that these institutions would only exacerbate the problems of international debt and world inflation. The IMF, the same as the WTO now, is an institution that is designed to lead governments into regulations under the guise of harmonization and to support a bureaucracy conveying the impression that world trade depends on agreements among governments, not on spontaneous cooperation among producers and consumers. Razeen Sally (1998) shows that a libertarian concept of international policy seeks unsubsidized and unmanaged free trade in decentralized political institutions. Jan Tumlir (1985) was also a strong opponent of international government intervention. Hazlitt (1984) says that, as problems of balance of payments usually result from domestic disorder, a super-governmental organization designed to give out foreign aid to balance trade tends to subsidize bad economic policies. So, the WTO should be abolished, along with the World Bank, the Federal Reserve System, and every other engine of inflation and statism in the world.

\section{Conclusion}

In this article we have seen that Mises poses something of an elitist theory, in which entrepreneurs seem to have a special perception of the future. This psychological classification of agents is based on the Cantillon-Bentham tradition, in which the entrepreneur is a special agent with greater forecast ability; as against Say and Menger's works, which define the entrepreneur as an organizer of labour. Contact between Mises and the Spann circle in Vienna was a determinant feature of his elitist vision of the entrepreneur. Although Spann defended nationalistic values and the whole, he also considered people to be unequal in qualities and thus suited to different positions in the social order. So he defended the idea that the individuals who demonstrate their leadership skills would rise among the levels of the hierarchy. Some Austrian economists have maintained Mises' elitism, by default or through personal belief, such as Fetter. However, other Austrian economists give less importance than does Mises to those special skills of the entrepreneur. They argue that the spreading of information in a market-oriented economy makes it impossible for an agent to foresee the future, be it the state or the entrepre- 
neur. The comparison between the arguments in favour of cooperative firms and those posed by different Austrian economists may clarify the definition of the agent presented by the Austrian School of Economics. The assumed inequality of the agents also affects their economic theory and the political arrangements that would emerge in a free society.

Another conclusion is that Mises' economic proposals are based on an optimistic sketch of the market; however, his social ideas are based on a pessimistic Hobbesian view of the nature of man. The market, as in Bentham's theory, is guided by its hero, the entrepreneur. But society is guided by the mass principle. And for Mises, the masses do not think.

\section{REFERENCES}

Armentano, Dominick T. (1999), Antitrust: the case for repeal, Auburn, LVMI.

Bentham, Jeremy (1818), Defence of Usury, London: Payne and Foss, Fourth ed. [1787].

Bies, R. J.; Tripp, T. M. and Neale, M. A. (1993), "Procedural fairness and profit seeking: The perceived legitimacy of market exploitation", Journal of Behavioural Decision Making, 6: 243-256. doi: 10.1002/bdm.3960060403

Bischof, Günter; PelinkA, Anton; LASSNER, Alexander (2003), The Dollfuss/Schuschnigg Era in Austria: A Reassessment, New Brunswick, NJ: Transaction Publishers.

Boettke, Peter, (2004), Anarchism as a Progressive Research Program in Political Econo$m y$, George Mason University, Working papers in Economics.

Brewer, Anthony (1992), Richard Cantillon: Pioneer of Economic Theory, London: Routledge.

- (1988), "Cantillon and Mercantilism". History of Political Economy. 20 (3): 447-460.

Brunner, K. and Meckling, W. (1977), "The Perception of Man and the Conception of Government”, Journal of Money, Credit and Banking, 9 (1), 70-85. doi: 10.2307/1992000.

CANTILlon, Richard (1755), Essai sur la Nature du Commerce en Général, London: Fletcher Gyles.

Cardoso, José Luís and Psalidopoulos, Michalis (2016), The German Historical School and European Economic Thought, London and New York: Routledge.

CARson, Kevin A. (2004), Austrian and Marxist Theories of Monopoly-Capital: A Mutualist Synthesis, Libertarian Alliance.

CARTER, Alan (1989) “'Self-exploitation' and Workers' Co-operatives - or how the British Left get their concepts wrong", Journal of Applied Philosophy VL-6, IS-2, 195-200.

- (1992), "Institutional exploitation? And workers' cooperatives - or how the British Left persist in getting their concepts wrong", The Heythrop Journal, 33, 4, 426.

- (2013), A Radical Green Political Theory, London and New York: Routledge.

Chaloupek, Günther (2006), "Approaches of the Austrian School to the Soziale Frage before World War I - Wieser and Böhm-Bawerk", Journal of Economic Studies, vol. 33, Iss: 3 , pp. $177-188$ 
Dube, Allison (1990), "Hayek on Bentham", Utilitas. A Journal of Utilitarian Studies, vol. 2, no. 1, May, Oxford: Oxford University Press, pp. 71-87.

Ebeling, Richard (1993), Global Free Trade: Rhetoric and Reality, Hillsdale: Hillsdale College Press.

- (1994), Can Capitalism Cope? Free Market Reform in the Post-Communist World, Hillsdale: Hillsdale College Press.

- (1995), "World Peace, International Order and Classical Liberalism", International Journal of World Peace, December.

- (1996), "The Global Economy and Classical Liberalism: Past, Present and Future", The Future of American Business, Hillsdale: Hillsdale College Press.

FetTer, Frank A. (1977), Capital, Interest, and Rent: Essays in the Theory of Distribution, (ed.) Murray N. Rothbard, Kansas City, Mo.: Sheed Andrews and McMeel.

- (1915). Economic Principles, New York: The Century Co.

Forget, Evelyn L. (1999), The Social Economics of Jean-Baptiste Say: Markets and Virtue, London: Routledge.

Foss, Nicolai J. (1997), "Austrian Insights and the Theory of the Firm”, Advances in Austrian Economics, 4: 175-98.

- and Klein, Peter G. (eds.) (2002), Entrepreneurship and the Firm: Austrian Perspectives on Economic Organization, Aldershott, UK: Edward Elgar.

- and Klein, Peter G. (2012), Organizing Entrepreneurial Judgment: A New Approach to the Firm, Cambridge: Cambridge University Press.

GARrison, Roger W. (1994) (1995), "Equilibrium and Entrepreneurship", Advances in Austrian Economics, vol. 2, part A, 67-78.

Gordon, David (1996), "What Remains of Socialism?" Review of The Philosophy and Economics of Market Socialism: A Critical Study, by N. Scott Arnold, The Mises Review, 2, no. 2 (Summer 1996).

Hayek, Friedrich A. von (1945), "The Use of Knowledge in Society", American Economic Review 35, 4, September, 519-30.

- (1960), The Constitution of Liberty, Chicago,:University of Chicago Press.

- (1976), Denationalisation of Money: The argument refined, UK: Lancing, Sussex, The Institute of Economic Affairs.

- (1988), The Fatal Conceit, Chicago: University of Chicago Press.

- (1992), "Carl Menger (1840-1921)" in The Collected Works of F. A. Hayek, Volume IV: The Fortunes of Liberalism: Essays on Austrian Economics and the Ideal of Freedom, (ed.) Peter G. Klein, Chicago: The University of Chicago Press, p. 62.

HazlitT, Henry (1984), From Bretton Woods to World Inflation, Chicago: Regnery Gateway.

Heertje, Arnold and Jan Middendorp (ed.) (2006), Schumpeter on the Economics of Innovation And the Development of Capitalism, London: Edward Elgar Publishing.

HuerTA DE Soto, Jesús (2000), La escuela austríaca, mercado y actividad empresarial, Madrid: Síntesis. 
Hülsmann, Jörg Guido (2007), Mises: The Last Knight of Liberalism, Alabama: Ludwig von Mises Institute.

Hülsmann, Eric (1989), "Autobiographical Reflections", vol. 34 of the Collected Works of Eric Voegelin, Baton Rouge: Louisiana State University Press.

Khan, M. S. (1954), “Adam Smith's Theory of Economic Development (in Relation to underdeveloped Economies)", Indian Journal of Economics, vol. 34, pp. 337-42.

KIRZNER, Israel M. (1979), "Knowing about Knowledge: A Subjectivist View of the Role of Information", in Kirzner, Perception, Opportunity and Profit: Studies in the Theory of Entrepreneurship, Chicago: University of Chicago Press, pp. 137-53.

- (1989), Discovery, Capitalism and Distributive Justice, New York: Basil Blackwell.

- (1997) "Entrepreneurial Discovery and the Competitive Market Process", Journal of Economic Literature, March, vol. Xxxv, n1, pp. 60-85.

Marshall, Alfred (1890), Principles of Economics (1st ed.), London: Macmillan.

Menger, Carl, (1976 [1871]), Principles of Economics, Alabama: Ludwig von Mises Institute.

Mises, Ludwig von (1932), The Market Economy, Jena: Gustav Fischer.

- (1961), "On Equality and Inequality" in Mises (1990), Money, Method, and the Market Process: Essays by Ludwig von Mises, Richard M. Ebeling (ed.), Nonuell, Mass.: Kluwer, pp. 190-201.

- (1963), Human Action, Chicago: Contemporary Books Inc. [1949].

- (1969) The Historical Setting of the Austrian School of Economics, New Rochelle, NY: Arlington Houseg.

- (1978), Notes and Recollections, South Holland, IL: Libertarian Press.

- (1981a), Socialism: An Economic and Sociological Annlysis, Indianapolis: Liberty Classics [1922].

- (1981b), The Theory of Money and Credit, Indianapolis: Liberty Fund [1912].

- (1990), "Observations on the Cooperative Movement", in Money, Method and the Market Process: Essays by Ludwig von Mises, Auburn, Ala.: The Ludwig von Mises Institute, 238-79 [1947].

- (2003), Epistemological Problems of Economics, Auburn, Alabama: Ludwig von Mises Institute [1933].

Moser, John (1997), "Origins of the Austrian School of Economics", Humane Studies Review, vol. 11, no. 1 (Spring).

Müller, Adam (1812), Die Theorie der Staatshaushaltung und ihreForschritte in Deutschland und England seit Adam Smith (2 vols.), Vienna.

Nevin, Séamus (2013), "Richard Cantillon - the Father of Economics", History Ireland, 21(2), 20-23. Retrieved from http://www.jstor.org/stable/41827152

O’NeILl, John, (1991), "Exploitation and workers co-operatives: a reply to Alan Carter", Journal of Applied Philosophy, vol. 8, Issue 2, 231-235 
- (1998) The market: ethics, knowledge and politics, London and New York: Routledge.

Pennington, Mark (2000), Planning and the Political Market: Public Choice and the Politics of Government Failure, Athlone Press.

Pesciarelli, Enzo (1989), "Smith, Bentham and the development of contrasting ideas on entrepreneurship", History of Political Economy, 21, 3, 521-536.

Preston, Keith, (2003) "Philosophical Anarchism and the Death of Empire", American Revolutionary Vanguard, http://www.attackthesystem.com/philo.html

PrychitKo, David (2005), What is Austrian Economics, http://www.oswego.edu/ prychitk/ austrian.html.

Raimondo, Justin, (2000), An Enemy of the State: The Life of Murray N. Rothbard, Amherst, NY: Prometheus Books.

Robertson, D. (1923), The Control of Industry, Hitchin, Herts: Nisbet.

RöPKE, Wilhelm (1959), International Order and Economic Integration, Dordrecht, Holland: D. Reidel.

Rothbard, Murray (1962), Man, Economy and State, Princeton: D. Van Nostrand.

- (1965), "Left and Right: The Prospects For Liberty", Left and Right: A Journal of Libertarian Thought, Spring.

- (1974), "Competition and entrepreneurship. By Israel M. Kirzner. Chicago and London: [University of Chicago Press], 1973. Pp. x, 246. \$7.95”, Journal of Economic Literature, 12 (3): 902-904

- (1978), For a New Liberty, New York: Collier Macmillan Publishers.

- (1982), The Ethics of Liberty, Atlantic Highlands: Humanities Press.

- (2000), Egalitarianism: A Revolt Against Nature, and other essays, Alabama: Ludwig von Mises Institute.

SAlerno, Joseph T. (2000), "Carl Menger: The Founder of the Austrian School” (at Mises Institute, https://mises.org/library/biography-carl-menger-founder-austrian-school1840-1921).

- (2008), “The Entrepreneur: Real and Imagined”, Quarterly Journal of Austrian Economics, 11 (3): 188-207.

SAlly, Razeen (1998), Classical Liberalism and International Economic Order: Studies in Theory and Intellectual History, London: Routledge.

SANTOS, Manuel (1997), Los economistas y la empresa. Empresa y empresario en la historia del pensamiento económico, Madrid: Alianza.

SAY, Jean-Baptiste (1836), Traité d'économie politique. A treatise on political economy or The production, distribution, and consumption of wealth, translated from the fourth edition of the French, Philadelphia: Grigg \& Elliot [1803].

Schumpeter, Joseph A., 1934 (2008), The Theory of Economic Development: An Inquiry into Profits, Capital, Credit, Interest and the Business Cycle, New Brunswick (USA) and London (UK): Transaction Publishers.

- (1969), Ten Great Economists: From Marx to Keynes, New York: Oxford University Press. 
- (1942), Capitalism, socialism and democracy, New York : Harper \& Brothers.

SchweICKArt, David (1993), Against Capitalism, Cambridge: CUP.

Shmanske, Stephen (1994), "On the Relevance of Policy to Kirznerian Entrepreneurship", Advances in Austrian Economics, vol. 1, 199-222.

Smith, Adam, (1976), An Inquiry into the Nature and Causes of the Wealth of Nations, The Glasgow Edition of the Works and Correspondence of Adam Smith, vol II, volume 1 and 2, edited by R. H. Campbell and A. S. Skinner, textual editor W. B. Todd., Indianapolis: Liberty Classics, Oxford University Press.

SPAnN, Othmar, (1921), Der wahreStaat, Leipzig: Verlag von Quelle und Meyer.

- (1930), Types of Economic Theory, London: George Allen and Unwin.

SPENGLER, Joseph J., (1975), "Adam Smith and society's decision-makers", in Essays on Adam Smith, Skinner, A. S. and Wilson T. (eds.), Oxford, pp. 397-400.

STARK, Werner (1946), "Jeremy Bentham as an Economist", Economic Journal, vol. 56, 224, pp. 583-608.

- (1952), Jeremy Bentham's Economic Writings, critical edition based on his printed works and unprinted manuscripts, vol. 2, London: published for The Royal Economic Society by George Allen \& Unwin LTD.

STReissler, Erich, (1988) "The Intellectual and Political Impact of the Austrian School of Economics", History of European Ideas, 9 (2), 191-204.

Sunic, Tomislav (1990), Against Democracy and Equality: The European New Right, New York: Peter Lang Publishing.

Tarascio, Vincent J. (1985), "Cantillon's Essai: A Current Perspective", Journal of Libertarian Studies, United States. 29 (2): 249-257.

Trincado, Estrella (2004), "Bentham. Precursor de los Austriacos", Procesos de Mercado, Revista Europea de Economía Política, 2(2), 119-49.

- (2006), "Adam Smith criticism of the doctrine of utility: a theory of the Creative Present", in Montes, Leonidas and Schliesser, New Voices on Adam Smith, New York and London: Routledge, pp. 313-327.

- (2009), “Teorías del valor y la función empresarial”, Investigaciones de historia económica, 14, pp. 11-38

Tucker, Jeffrey A. and Rockwell, Jr, Llewellyn H. (1991), "The Cultural Thought of Ludwig von Mises", The Journal of Libertarian Studies, vol. X, no. 1, Fall.

TuMLIR, Jan (1985), "Conceptions of the international Economic and Legal Order", The World Economy, 9, 85.

Wasserman, Janek (2010), Black Vienna, Red Vienna: The Struggle for Intellectual and Political Hegemony in Interwar Vienna, 1918-1938, PhD dissertation, Washington University. 


\title{
The debate between the Austrian School of Economics and the cooperative movement. The assumption of unequal perception among agents
}

\begin{abstract}
In the economic theory of the Austrian School, the market process is driven by entrepreneurial alertness, or discovery, where the subjective perception of information is an essential element. According to Mises, this perception is unequal in different agents, as entrepreneurs are talented individuals that respond to encouragement. But some other Austrian economists defend cooperative arrangements, assuming that everybody has some entrepreneurial skill and could be the owner and manager of the firm. This article poses the question of whether or not it is necessary that the Austrian School of Economics defends an unequal psychology of agents that would preclude cooperative businesses from the market economy. It concludes that Mises' contact with the Spann circle in Vienna was determinant in the creation of his elitist vision of the entrepreneur.
\end{abstract}

KEYWORDS: entrepreneurship, Austrian economics, cooperative movement, alertness, market economy

JEL CODES: B53, 031

\section{El debate entre la Escuela Austríaca de Economía y el movimiento coope- rativo. ¿Existe una capacidad de percepción desigual entre los agentes?}

\section{RESUMEN}

En la teoría austriaca de economía, el mercado se mueve gracias a la capacidad de alerta, o el descubrimiento, del emprendedor, donde la percepción subjetiva de información es un elemento esencial. Según Mises, esta percepción es desigual en diferentes agentes, dado que los empresarios son individuos con un talento especial que necesita estímulo. Pero otros economistas austriacos defienden las organizaciones cooperativas, suponiendo que todos tenemos habilidades emprendedoras y podemos ser el propietario y organizador de la empresa. Este artículo se plantea si es necesaria para la Escuela Austriaca de Economía la defensa de una psicología desigual de los agentes que descarta la defensa de las organizaciones cooperativas. Concluye que el contacto de Mises con el círculo Spann en Viena determinó su visión elitista del empresario.

PALABRAS CLAVE: empresarialidad, economía austriaca, movimiento cooperativo, capacidad de percepción, economía de mercado

Códigos Jel: B53, 031 